\title{
Creativity and discovery
}

\author{
A meeting of the scientific and artistic minds bigblights the DNA of Madison
}

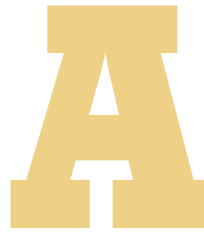

moment of sterling clarity and breath taking beauty occurred on this campus this semester, and I was proud to be a part of it.

Francis Collins, chief of the National Institutes of Health and former director of the landmark Human Genome Project, visited JMU to lecture about genetics as part of a yearlong university series on this complex science and its equally complex societal implications.

This renowned geneticist and physician gave us a glimpse of the

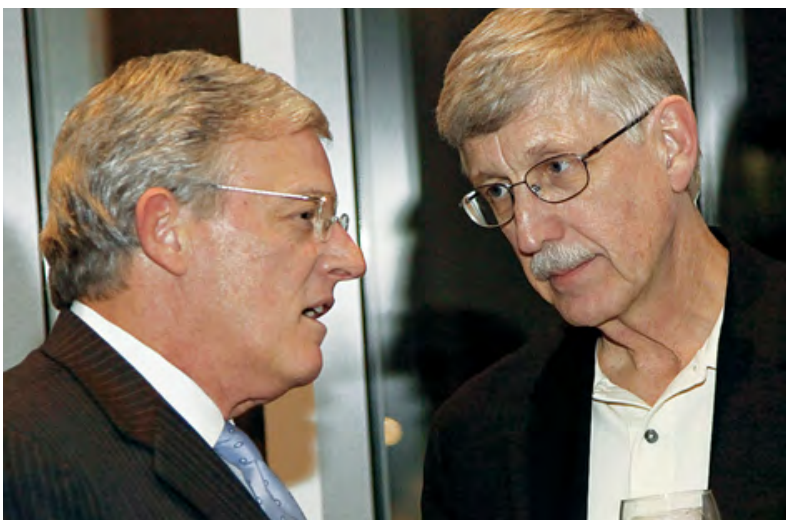

JMU President Linwood H. Rose talks with Francis Collins, chief of the National Institutes for Health, at the culmination performance of JMU's yearlong Dance of Art and Science initiative. scientific mind in top form when he said, "... where science becomes something exciting and enormously significant is when you take that creative leap and say, 'I have this wild crazy idea that life works that way. Let's design a really creative experiment and see if we're right' — and we're usually wrong."

In response, McArthur Genius Award winner and equally renowned choreographer Liz Lerman (also on campus for the occasion) said, "But then there's something in the room to work with. Then you have something. Before you had nothing. ... Most artists are like that."

Lerman and Collins had revealed something momentous - creativity fuels both art and science, and creativity leads to discovery. Collins described how his creative leap and early failure ultimately led to a clinical trial to treat an extremely rare genetic disease. Lerman explained how early ideas led ultimately to artistic breakthroughs, including the creation of Ferocious Beauty: Genome, which her company performed prior to the audience discussion.

The exchange between these two creative minds affirmed the value of the cross-disciplinary and collaborative approaches to education that is cultivated at JMU. Our approach sparked this yearlong Dance of Art and Science initiative that brought these two prodigies to campus. It started by welcoming our freshmen at Orientation with the "DNA Dance on the Quad," encompassed master classes, exhibits, performances and the opening of the Forbes Center for the Performing Arts.

In my estimation, the Dance of Art and Science went further. It revealed the unique DNA of James Madison University. Nowhere else in higher education does this degree of cross-disciplinary collaboration occur so regularly, with such impact. What we deliver better than any other educational institution is a broad knowledge-based perspective combined with a depth of disciplinary competency and a propensity for engagement that leads to graduates equipped to make a difference in a world that is so intricately interconnected.

The field of genetics has begun to transform the health care and medical fields and provides entrepreneurial opportunities that stimulate our icence of the JMU arts experience. The gala showcased our new performance venues, the teaching and learning spaces, and our generous donors who made them possible.

Just after the Forbes Center gala, we received word of a significant recognition for the College of Business. Known for its Integrated Functional Systems class, the CoB is ranked 28th in the nation among public and private undergraduate business schools according to Bloomberg Businessweek's annual rankings. In 2010, the CoB ranked 41st and in 2008, 54th. This year among public institutions, JMU's Col-

lege of Business ranks $11 \mathrm{th}$. This jump in the rankings is due to a committed and talented faculty.

I am pleased also to report, this year the Virginia General Assembly added $\$ 6.1$ million in state funding
infusion is a permanent reversal of the trends experienced in the last three years of budget reductions for higher education. This budget includes funding for enrollment growth of 100 students, an increase in full-time faculty members, operation and maintenance of new buildings and additional financial aid. I'm also hopeful that this funding signifies an acknowledgment of the vital role higher education plays in the health of our economy and our society.

There is no better example of this vital role than JMU's selection for the 2010 Community Engagement Classification by the Carnegie Foundation for the Advancement of Teaching. The honor recognizes the breadth and depth of JMU's relationship with the wider community. This mutually beneficial partnership is part of the DNA of JMU - community involvement, collaboration, creativity. Again, the words of Dr. Collins illustrate the worth of what we do at JMU: "What we humans have been gifted with is the ability to think beyond the obvious. That's what we are all hungry somehow to do."

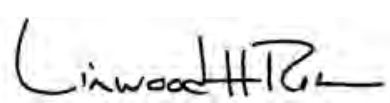

Linwood H. Rose, President James Madison University 